\title{
The Influence of Project-based Learning Strategy and Self-regulated Learning on Academic Procrastination of Junior High School Students' Mathematics Learning
}

\author{
Dahlia Novarianing Asri", Punaji Setyosari, Imanuel Hitipeuw, Tutut Chusniyah \\ State University of Malang, Indonesia, IKIP PGRI, Madiun, Indonesia \\ *Corresponding author: novarianing@gmail.com
}

\begin{abstract}
The objective of this study is to obtain conclusions concerning different levels of junior high school students' academic procrastination in learning mathematics by applying a project-based learning strategy and a conventional learning strategy. The different levels of junior high school students' academic procrastination depend on high or low self-regulated learning and the interaction effects of project-based learning strategies and selfregulated learning in accordance with academic procrastination of junior high school students in learning mathematics. Experimental research design was used in this quasi-experimental research, along with its cluster random sampling technique. The data collection instrument was self-regulated learning and academic procrastination scales. The data analysis techniques to test hypotheses was a two-way Anava track. The result shows (1) differences in the levels of academic procrastination in learning mathematics for junior high school students who got the projectbased learning strategy and conventional learning strategy, (2) differences in the levels of academic procrastination for junior high school students who had low self-regulated learning, and (3) an interaction effect of project-based learning and self-regulated learning strategies on academic procrastination of junior high school students in learning mathematics.
\end{abstract}

Keywords: project-based learning strategies, self-regulated learning, conventional learning strategy, academic procrastination, learning mathematics

Cite This Article: Dahlia Novarianing Asri, Punaji Setyosari, Imanuel Hitipeuw, and Tutut Chusniyah, "The Influence of Project-based Learning Strategy and Self-regulated Learning on Academic Procrastination of Junior High School Students' Mathematics Learning." American Journal of Educational Research, vol. 5, no. 1 (2017): 88-96. doi: 10.12691/education-5-1-14.

\section{Introduction}

Compared with mathematics achievements of students in other countries worldwide, Indonesian students' mathematics achievements remain low. The research results of the 2012 PISA (Program for International Student Assessment), a study focusing on reading literacy, mathematics, and science show that Indonesia ranked the top 10 bottom of 65 participating countries. Another research result by TIMSS (Trends in International Mathematics and Science Study) in 2011 in the fields of mathematics and science for students in grade 2 of junior high schools shows that more than $95 \%$ of students in Indonesia was only able to reach the middle level, while other countries such as Taiwan, nearly $50 \%$ of its students are able to achieve a high and advanced level (Ministry of Education and Culture, 2013).

One cause of low mathematics learning achievement is a high level of students' academic procrastination. According to Schraw et al. [24], academic procrastination is a behavior that deliberately delays or postpones the work to be done. Students who are procrastinating do not have a stimulus to activities that should be done in time. Steel [29] considers procrastination as a destructive behavior because it interferes with academic achievements.

Clark and Hill's research (1994) showed that $28 \%$ of students put off studying for exams, $36 \%$ delayed reading a textbook, and $30 \%$ of students postpone working on written assignments. Studies conducted by Zeenath and Orcullo [34] found that of 287 students in Malaysia who would take the test, $80 \%$ of them experienced procrastination, along with details of $32.5 \%$ prepared for the test two weeks early, $20 \%$ prepared for the exams at the last minute. After completing the task, students preparedness depends on their mood, so that the majority of students experienced procrastination in preparing for the test. Safira and Suharsono's research (2013) showed that junior high schools taking an acceleration program in Malang had a high level of academic procrastination $(52.1 \%)$, while $47.9 \%$ was classified as a low level of procrastination.

The occurrence of procrastination indicates failure in self-regulated learning. Self-regulated learning takes place when students retaining the learning processes are able to organize and direct themselves, enabling to adjust and control themselves, especially when facing difficult tasks. 
Students who have a self-regulation in learning are able to set goals, plan, and use effective learning strategies. Conversely, students who have low a self-regulation have often failed to implement effective learning strategies. According to Smith [28], self-regulated learning is important to students to develop the capacity that contributes to successful learning.

Effects of self-regulated learning on academic procrastination are discussed in some studies. Steel's Research [29] showed a negative relationship between academic procrastination and the level of self-regulation. In addition, Eerde's research [9] states that an academic procrastination behavior shows a lack of self-regulation, such as the use of strategies and monitor the learning process, and tend to avoid tasks. Some researchers $[9,10,33]$ argued that self-regulation is one of the most powerful predictors of the emergence of academic procrastination.

The high level of academic procrastination in learning mathematics is also influenced by the teachers' choice of learning strategies. From the interviews in the study, it indicates that many teachers use conventional learning strategies. This condition is supported by the results of Ardhana and Purwanto's research [1] in Buleleng, Bali and Malang where $80 \%$ of teachers still used the lecture method in teaching sciences. The students' views show that $90 \%$ of teachers teach by explaining (lectures) and rarely observe outside of the classroom.

Conventional learning strategies tend to evoke a sense of boredom, laziness, and tiresome for students. For this reason, teachers must design a classroom environment and learning instruction that support the development of students' competence. Lessons should be served with a variety of interesting ways, fun, and can be applied in everyday life [4]. One of the strategies that can be applied to mathematics to lower the level of a student's academic procrastination is a project-based learning strategy. Implementing project-based learning strategies in mathematics refers to the opinion of Freuental (in Gravemeijer, 1994) which states that learning mathematics should be associated with reality and human activity. Mathematics should be connected to reality, to be close to the students, and relevant to people's lives in order to have human values. Moreover, learning materials must be transmitted through mathematics as a human activity. Education should provide students with an opportunity to "re-invent" (to find/recreate) mathematics through practice (by doing it).

As empirically proven, the project-based learning can improve academic achievement [31]. Alamaki's study [2] showed that the project-based learning is innovative, unique, and focuses on problem-based inquiry related to students' life or the needs of the local community or the industry. Results of Fitzmaurice and Donnelly's research [12] showed that project-based learning is an instructional strategy that focuses on concepts and principles of discipline, engage students in problem-solving and other meaningful tasks, giving students the chance to organize their own learning and ultimately produce the real work [12].

As previously described, in the learning and teaching of mathematics, teachers need to design a learning strategy that is deemed to lower academic procrastination by involving self-regulated learning and students. Therefore, this study was conducted to obtain conclusions concerning different levels of academic procrastination in learning mathematics for junior high school students who got a project-based learning and conventional learning strategies. The different levels of academic procrastination in learning mathematics are important to junior high school students who have high or low self-regulated learning, and interaction effects of project-based learning and self-regulated learning strategies in relation to academic procrastination in learning mathematics.

\section{Research Design}

This research used an experimental research design. This type of research experiments used a quasi-experimental study (a quasi-experiment), because in this study, it is impossible to control all the variables expected to influence or impact the treatment of behavors $[6,19]$.

The variables of this research consist of independent variable, moderator variable and dependent variable. The independent variable is a learning strategy, which is divided into two parts namely project-based learning and conventional learning strategies. The moderator variable is self-regulated learning, which is divided into two parts namely self-regulated learning and low self-regulated learning, while the dependent variable is the academic procrastination.

The influence of independent variable on the dependent variable, and its interaction with the moderator variable is designed by using a factorial design of $2 \times 2$ with a pretest-posttest control group design. The design articulates three components: (1) The main effect of the variable treatment of based-learning strategy projected on the academic procrastination in learning mathematics; (2) the effect of students who have high and low selfregulated learning against academic procrastination in learning mathematics; and (3) the effect of the interaction of project-based learning strategies and self-regulated learning on the academic procrastination in learning mathematics.

\section{Population and Sample}

The population in this study was all students of grade VII throughout Madiun Regency-based junior high schools where the school-based curriculum (SBC) was implemented, involving 2414 students spreading over 25 schools. Using a random sampling technique, this study population is worth considering because a large-sized random chance is given to members of the population as a group. Thus, sampling was conducted in groups (clusters), and the sample collection technique is also called a random cluster sample [7].

The sample members in this random cluster sampling technique can be obtained in 6 schools, and the determination of 6 schools is considered representative in comparison to the total population. Members of selected samples are students of class VII at SMPN 1 Jiwan, SMPN 1 Wungu, SMPN 2 Mejayan, SMPN 2 Geger, SMPN 2 Saradan, and SMPN 3 Kare. In each of the 
schools that the research samples two classes involved randomly, i.e., one class was the experimental group and one class was the control group, so the overall number of classes used as samples were 12 classes.

A number of sample members derived from 6 schools were 306 students. After analyzing the self-regulated learning category, 12 members of samples were not included because of a range of fluctuations, meaning that the research subjects consist of 294 students, divided into 145 students in the experimental group and 149 students in the control group.

\section{Research Instruments}

The instrument used to collect data in this research is a scale of self-regulated learning and an academic procrastination scale. A self-regulated learning scale is adapted from Motivated Strategies for Learning Questionnaire (MSLQ) based on Pintrich et al. [21] involving two major aspects, namely (1) motivation, which consists of three indicators, namely (a) value component, (b) expectancy component, (c) affective component, and (2) learning strategies consist of two indicators, namely (a) cognitive and metacognitive strategies, and (b) resource management strategies. The scale of self-regulated learning has 81 items used to determine which groups of students have a high level of self-regulated learning and a low level of self-regulated learning. Determining the category of students with high self-regulated learning and self-regulated learning results from using a lower limit of the range score fluctuation or the mean score [3].

The scale of academic procrastination in this research adapted from the procrastination scale by Tuckman [32] depends on three aspects of academic procrastination, namely (1) the pictures in general are against the tendency to delay the work, (2) the tendency to avoid duties and terms - unpleasant things due to difficulties in the work, and (3) the tendency to blame others in certain situations. The academic procrastination scale has 35 items presented in the form of both favorable and unfavorable statements, using five alternative answers.

In practice, the levels of these instruments' validity and reliability are measured accordingly. The test validity covers the construct validity and empirical validity. Construct validity test results state that the overall scales of self-regulated learning and academic procrastination scale have to be used as a measuring tool because it pertains to theoretical constructs and existing dimensions. The test of empirical validity show that (1) 81 item scales of self-regulated learning are prepared containing 10 items that otherwise decrease in number so that a number of valid items were 71 items, and (2) of 35 item scales of academic procrastination, 4 of them fall, so that a number of valid items were 31 items. The test reliability deals with Cronbach's Alpha formula reliability coefficient of selfregulated learning worth 0.952 and the academic procrastination reliability coefficient of 0.897 . This means that the scale of self-regulated learning and academic procrastination scale is otherwise reliable.

\section{Data Analysis}

The data analysis is categorized as descriptive in nature, along with test requirements, and inferential data analysis. This descriptive data analysis is intended to facilitate the observation of statistical data obtained by a statistical calculation. A prerequisite test includes a normality test by using Kolmogorov-Smirnov's test, a homogeneity test, Levene's test, tests of balance and independent tests techniques. Inferential data analysis is designed to test the hypothesis by using a two-way Anova track.

\section{Research Results}

\subsection{Descriptive Data Analysis}

A descriptive data analysis includes a description of self-regulated learning data and academic procrastination data description based on the mathematics learning: a learning strategy, self-regulated learning, and the group of cells (interaction strategies for learning and self-regulated learning). Data from the measurement of self-regulated learning are samples of the experimental group or the control group, as described in Table 1 below.

Based on the results of data analysis pretest and posttest academic procrastination in learning mathematics in the experimental group and the control group, the difference may be determined average score of pretest and posttest results of academic procrastination in learning mathematics between the experimental group and the control group. Description of the comparison data and the difference between the average score pretest and posttest results of academic procrastination in learning mathematics in the experimental group and the control group are presented in Table 2 below.

Table 1. A Number of Students Based on Self-Regulated Learning Levels

\begin{tabular}{llc}
\hline & \multicolumn{2}{c}{ Self-Regulated Learning } \\
\cline { 2 - 3 } & High & Low \\
\hline $\begin{array}{l}\text { Experiment group (the project-based } \\
\text { learning) }\end{array}$ & 70 & 75 \\
Control group (the conventional learning) & 81 & 68 \\
\hline Total & 151 & 143 \\
\hline
\end{tabular}

Table 2. The descriptive data of different score average of pretest and posttest results concerning academic procrastination in mathematics learning in experiment group and control group

\begin{tabular}{|c|c|c|c|c|c|}
\hline \multicolumn{6}{|c|}{ Independent Variable: Academic Procrastination in Mathematics Learning } \\
\hline & $\mathrm{N}$ & pretest mean & posttest mean & Variant & decrease $(\%)$ \\
\hline Experimental group & 145 & 108.94 & 62.17 & 46.77 & $42.93 \%$ \\
\hline Control group & 149 & 110.79 & 85.19 & 25.60 & $23.11 \%$ \\
\hline
\end{tabular}


Table 2 shows differences in the average score (mean) that rest on results of pretest and posttest concerning the academic procrastination in learning mathematics in the experimental group and the control group. In essence, results of pretest in the experimental group and the control group almost show the same score worth 108.94 for the experimental group and 110.79 for the control group. This indicates that prior to the treatment, the level of academic procrastination in the two groups balanced. Results of posttest pertaining to academic procrastination in learning mathematics after the treatment show a decrease by 62.17 in the average score and by 85.19 in the experimental group and the control group. The decline in the average score of $42.93 \%$ occurred in the experimental group and by $23.11 \%$ in the control group. Thus, the decline of academic procrastination in the experimental group was greater than the decline in academic procrastination in the control group.

The results of pretest and posttest evidence that academic procrastination in learning mathematics is based on self-regulated learning, and the difference between the average score of pretest and posttest results of academic procrastination determines whether or not a group has a high level of self-regulated learning or a low level of self-regulated learning groups. The description of compared data and the difference between the average score of pretest and posttest results of academic procrastination is based on the self-regulated learning, as presented in Table 3.

Referring to Table 2, the average score (mean) results of pretest concerning the academic procrastination in learning mathematics in the experimental group and the control group show almost the same score worth 108.94 for the experimental group and 110.79 for the control group. This indicates that prior to the treatment, the level of academic procrastination in the two groups are balanced. Results of postest of academic procrastination in learning mathematics after treatment show a decrease by 62.17 in the average score of the experimental group and by 85.19 for the control group. The decline by $42.93 \%$ in the average score of experimental group and by $23.11 \%$ for the control group. Thus, the decline in the academic procrastination in the experimental group was greater than the decline in academic procrastination in the control group.
Results of pretest and posttest data analysis on the academic procrastination in learning mathematics based on the self-regulated learning show the difference between the average score of pretest and posttest results of academic procrastination among a group of high selfregulated learning and lower self-regulated learning groups. The description of the comparison data and the difference between the average score of pretest and posttest results of academic procrastination is based on the self-regulated learning presented in Table 3 below.

Differences in the average score (mean) results of pretest and posttest concerning the academic procrastination in learning mathematics among a group of high self-regulated learning and lower self-regulated learning groups listed in Table 3 is worth presenting.

The average score (mean) results of pretest concerning the academic procrastination in learning mathematics in a hight self-regulated learning group show almost the same results with a low self-regulated learning group, namely the high self-regulated learning group is worth 113.72 and the low self-regulated learning group is worth 105.85. This indicates that the level of academic procrastination in learning mathematics in both groups is balanced. In addition, the result of posttest of academic procrastination in learning mathematics in the high self-regulated learning group is 70.95 and in the low self-regulated learning is 77.03. The decline by $37.61 \%$ in the average score of a higher self-regulated learning group and by $27.23 \%$ in a lower self-regulated learning group. It can be concluded that the decline in the academic procrastination in a higher self-regulated learning group is greater than the decline in the academic procrastination in a low self-regulated learning group.

Furthermore, pretest and posttest data of the academic procrastination in learning mathematics against four groups of cell research can determine the difference between the average score of pretest and posttest results of academic procrastination in learning mathematics in 4 groups of cells research, as presented in Table 4 below.

Differences in the average score (mean) results of pretest and posttest concerning the academic procrastination in learning mathematics is based on the cell group research as shown in Table 4.

Table 3. The average score difference data on pretest and posttest results of academic procrastination in learning mathematics based on selfregulated learnining

\begin{tabular}{lccccc}
\hline \multicolumn{7}{c}{ Independent Variable: Academic Procrastination in Mathematics Learning } & & \\
\hline & $\mathrm{N}$ & pretest mean & posttest mean & variant & decrease (\%) \\
\hline High Self-Regulated Learnining Group & 151 & 113.72 & 70.95 & 42.77 & $37.61 \%$ \\
Low Self-Regulated Learnining Group & 143 & 105.85 & 77.03 & 28.82 & $27.23 \%$ \\
\hline
\end{tabular}

Table 4. A description of data on average score differences in pretest and posttest results concerning the academic procrastination in learning mathematics based on the cell group

\begin{tabular}{|c|c|c|c|c|c|}
\hline \multicolumn{6}{|c|}{ Independent variable: academic procrastination in learning mathematics } \\
\hline Cell group & $\mathrm{N}$ & pretest mean & posttest mean & variant & decrease $(\%)$ \\
\hline Experiment-high SRL & 74 & 111.90 & 58.84 & 53.06 & 47.76 \\
\hline Experiment-low SRL & 71 & 106.19 & 66.33 & 39.86 & 36.59 \\
\hline Control-high SRL & 72 & 115.25 & 83.06 & 32.19 & 27.93 \\
\hline Control-low SRL & 77 & 105.48 & 87.73 & 17.75 & 16.82 \\
\hline
\end{tabular}


The experimental group with a high self-regulated learning has decreased the average score (mean) of academic procrastination of pretest to posttest worth 53.06 $(47.76 \%)$, and it is successively followed by the experimental group of low self-regulated learning worth $39.86(36.59 \%)$, the control group with a high selfregulated learning of $32.19(27.93 \%)$, and the control group with a low self-regulated learning of 17.75 $(16.82 \%)$. To conclude, the overall decline in the academic procrastination in learning mathematics in the experimental group is greater than the decline in the academic procrastination in the control group.

\subsection{Testing Requirements Analysis}

Prior to the data analysis using a two-way Anova track, it is necessary to test prerequisites, which include normality test, homogeneity, and a balance test. Results of normality test data on the academic procrastination in learning mathematics using the Kolmogorov-Smirnov formula show the significance value that is greater than 0.05 ( $p>0.05$ ). Thus, the academic procrastination data were normally distributed. The test of homogeneity of variance using Levene's test generates a significant value that is greater than 0.05 ( $\mathrm{p}>0.05)$, so that the variant data is homogeneously academic procrastination. Further still, results of tests of balance with two different test averages (independent posttest) are worth 1.022 with a significance of 0.308 . Since $p>0.05$, the data on the academic procrastination in the learning of mathematics is balanced.

\subsection{Hypothesis Testing}

The data analysis technique used to test the hypothesis was a two-way Anava track. The criterion for testing the hypothesis is that Ho is rejected if the significance value of $p<0.05$. The analysis of data in the first hypothesis is generated through the value of $F_{\text {count }}$ worth 17.287 with a significance value of 0.000 . Because the $F_{\text {count }}$ of significance value is less than 0.05 , then Ho is rejected and H1 is accepted. Thus, there are significant differences in the level of academic procrastination in the learning of mathematics for junior high school students who received project-based learning strategies and junior high school students who received conventional learning strategies.

The data analysis of the second hypothesis is generated through a value of $F_{\text {count }}$ worth 5.589 with a significance of 0.019 . Because the $F_{\text {count }}$ of significance value is less than 0.05, then Ho is rejected and H1 is accepted. In short, there are significant differences in the level of academic procrastination in the learning of mathematics for junior high school students who have high self-regulated learning and junior high school students who have low self-regulated learning.

Furthermore, the data analysis of the third hypothesis of $F_{\text {count }}$ is 5.146 with a significance value of 0.024 . Because the $F_{\text {count }}$ value is less than 0.05 , then Ho is rejected and $\mathrm{H} 1$ is accepted. Therefore, there is an interaction effect of project-based learning strategies and self-regulated learning on academic procrastination in learning mathematics for junior high school students.

\subsection{Further Test}

A further test was conducted to determine differences in any group of research cells pertaining to group learning strategies and self-regulated learning groups. It was performed by using the Scheffe method. In line with the test results of multiple comparisons further known as the comparison between the learning strategies of projectbased learning and conventional learning strategies, the mean difference of 6.844 and significance of 0.000 can be obtained. Because the significance value is smaller or less than 0.05, then Ho is rejected. Thus, academic procrastination in learning mathematics between groups of project-based learning and conventional learning groups differ significantly.

As strongly evidenced, the comparison between students who have high and low self-regulated learning, the value of mean difference is 3.892 along with a significance value of 0.019 . Because the significance value is less than 0.05 , then the $\mathrm{Ho}$ is rejected. In conclusion, there is a significant difference in learning mathematics concerned with academic procrastination among groups of high and low self-regulated learning, as presented in Table 5 below.

Table 5. The test result of multiple comparisons among cells of Scheffe method

Multiple Comparisons

Dependent Variable: Academic procrastination in learning mathematics (Posttest)

Scheffe

\begin{tabular}{|c|c|c|c|c|}
\hline (I) Cell Groups & (J) Cell Groups & Mean Difference (I-J) & Std. Error & Sig. \\
\hline \multirow[t]{3}{*}{ PB Project-High SRL } & PB Project-low SRL & $-7.626^{*}$ & 2.340 & .015 \\
\hline & Convs-high SRL & $-10.578^{*}$ & 2.298 & .000 \\
\hline & Convs-low SRL & $-10.736^{*}$ & 2.397 & .000 \\
\hline \multirow[t]{3}{*}{ PB Project-low SRL } & PB Project-high SRL & $7.626^{*}$ & .015 & .015 \\
\hline & Convs-high SRL & -2.953 & .635 & .635 \\
\hline & Convs-low SRL & -3.110 & .629 & .629 \\
\hline \multirow[t]{3}{*}{ Convs-high SRL } & PB Project-high SRL & $10.578^{*}$ & .000 & .000 \\
\hline & PB Project-low SRL & 2.953 & .635 & .635 \\
\hline & Convs-low SRL & -.157 & 1.000 & 1.000 \\
\hline \multirow[t]{3}{*}{ Convs-low SRL } & PB Project-high SRL & $10.736^{*}$ & .000 & .000 \\
\hline & PB Project-low SRL & 3.110 & .629 & .629 \\
\hline & Convs-high SRL & -.157 & 1.000 & 1.000 \\
\hline
\end{tabular}


Table 5 shows test results of multiple comparisons between cells along with the Scheffe method applied for performance between cells of different test groups of learning strategy and self-regulated learning. If the criterion for decision-making is a decided formula of $\mathrm{a}=$ 0.05 , then the Ho is rejected if $p<0.05$. The results of data analysis are formulated as follows: (1) there are significant differences of academic procrastination in learning mathematics among cells groups of high project-based learning and low self-regulated learning, (2) there are significant differences of academic procrastination in learning mathematics among cells groups of high projectbased learning and self-regulated learning and the groups of high conventional learning and self-regulated learning, (3) there are significant differences of academic procrastination in learning mathematics among cells groups of high project-based learning and self-regulated learning and groups of low conventional learning and selfregulated learning, (4) there is no significant difference of academic procrastination in learning mathematics among cells groups of low project-based learning and selfregulated learning and the group of high conventional learning and self-regulated learning, (5) there are no significant differences of academic procrastination in learning mathematics among cells groups of low projectbased learning and self-regulated learning and the groups of low conventional learning and self-regulated learning, (6) there is no significant difference of academic procrastination in learning mathematics among cells groups of high conventional learning and self -regulated learning and low conventional learning and self-regulated learning groups.

\section{Discussion}

In terms of the first hypothesis test, there are significant differences in the level of academic procrastination in learning mathematics among junior high school students who received project-based learning strategies and junior high school students who received conventional learning strategies. The implementation of project-based learning strategies in the learning of mathematics is mainly concerned with the constructivist view in that individuals construct knowledge through interaction with the environment and each individual is a different construct of knowledge. Students' knowledge can be built through the construction of new knowledge obtained from researches and conversations or activities. Students interpret what was taught to adapt to their experience [17].

The decrease in the level of academic procrastination in learning mathematics through a project-based learning strategy occurs because the learning process is a strategy that provides an opportunity for students to be actively involved in building their knowledge and skills, and students are encouraged to be able to solve the problem and be able to implement project activities through the their skills. This insight is supported by Fitzmaurice and Donnelly's [12] which states that the project-based learning strategy is an instructional strategy focusing on the concepts and principles of discipline, engaging students in problem-solving activities and other meaningful assignments, giving students the chance to organize their own learning and eventually produce realistic results.

Research results confirm that project-based learning strategies can lower academic procrastination in learning mathematics for junior high school students supported by several studies. Results of Purworini's research [22] show that the project-based learning can improve students' learning outcomes, increase activities and engagement in learning, foster creativities in solving the problems, more fun, reward more meaningful tasks. Thomas's research [31] shows that the project-based learning can improve academic achievement. In addition, Alamaki [2] explains that the project-based learning is innovative, unique, and focuses on problem-based inquiry related to students' life or the needs of the local community or the industry.

Decreased levels of academic procrastination in learning mathematics as the direct effects of project-based learning strategies are substantive due to the emphasis on students' project-based learning activities to search, explore and discover the meaning of a subject matter. Students are trained to bring out the leadership in learning processes, modeling behaviors such as social interaction, leadership, innovation, self-reliance and creativity in doing the project so that students are directly involved in the learning processes. Conversely, the conventional learning is less emphatic in providing process skills (hands-on activities). This gives rise to less enthusiastic students in the learning processes, so that it becomes less meaningful to them and results in delaying the work and tasks assigned by the teacher. This is supported by the research conducted by Ardhana and Purwanto [1] in Buleleng, Bali and Malang through which $80 \%$ of teachers still use the lecture method in teaching sciences. The students' views reveal that $90 \%$ of teachers teach by explaining (lectures) and rarely observe outside of the classroom.

The project-based learning strategy is more influential than the conventional learning strategy in that it lowers the level of academic procrastination in the learning of mathematics. As a learning strategy based on more projects, it provides students with learning opportunities to work in teams, find the skills to plan, organize, negotiate and build a negotiation on issues of project tasks to be undertaken, the division of tasks and responsibilities of each student. More importantly, how the information will be presented, while conventional learning strategies give a conventional opportunity to explore the small-scale learning skills portions.

In view of this articulation, Blumenfeld et al. [5] state that the project-based learning provides a flexible learning environment and the achievement of competence thinking. Students have the opportunity to learn by doing, improve the ability to think and make up learning processes as participants in active learning. As Richmond and Striley [23] point out, an interactive process with fellow colleagues helps generate a knowledge construction process (a meaning-making process).

In accordance with the second hypothesis test, there are significant differences in the level of academic procrastination in learning mathematics among junior high school students who have high self-regulated learning and junior high school students who have low self-regulated learning. The results of this research indicate that self- 
regulated learning is required for students to understand how the learning processes are able to organize and direct them, adjust and control themselves, especially when facing difficult tasks. This is related to what Smith [28] states that self-regulated learning has clear goals to improve and renew skills, search for new knowledge, and solve problems in life. This is a potential students must own to be able to develop the capacity that contributes to success.

Students possessing a self-regulated learning strategy will determine the academic procrastination, or in other words, the academic procrastination indicates failure to self-regulate learning (the self-regulated learning). The research results outlines that students with high selfregulated learning levels of academic procrastination in learning mathematics are lower students who have low self-regulated learning. This is because students who have high self-regulated learning will generally be attracted to deal with materials being taught, prepare for learning in the classroom, and participate during in-class interactions by asking more questions or expressing ideas during inclass discussions.

When handling homework or academic work, students who have self-regulation will clarify the difficulties encountered, find the basic idea, sum up the materials they have read, and work with the linked theories and experience. In contrast, students who have low selfregulated learning often fail to implement effective learning strategies. This is closely related to Corno and Mandinach's insight (in [15]) that states that students who have self-regulated learning are able to set goals, plan, and use effective learning strategies. However, students who low self-regulated learning often fail to implement effective learning strategies.

Moreover, Corno and Mandinach (in [15]) outline that students who have self-regulated learning have three main features, namely the objectives, actions and assessment. In a sense, students create a new destination and new ways to maintain or achieve a goal, and change the way to measure it. Some other experts (Schunk, 1990; Zimmerman, 1999, Bandura, 1977; Bandura \& Cervone, 1983; in [11]) explicate that students who have self-regulation involve three activities: (1) students set challenging but achievable goals, (2) students choose and implement effective strategies to achieve their goals, and (3) students apply strategies of self-regulation in the form of self-observation, self-judgment, and self-administration as direct consequences to motivate and guide them during the learning processes.

Students performing academic procrastination in learning mathematics should have a self-regulated learning ability because Zimmerman and Moylan [37] accentuate that in the context of self-regulated learning, students are challenged to deal with (1) activities that are fun, such as watching television or chatting with friends, (2) lack of knowledge concerning a good learning management, (3) a difficulty in assessing the quality of one's learning, and (4) lack of appreciation. Attention, retention, self-awareness, and other issues of motivation have been studied as an important attribute to the students who have self-regulation.

To develop students' self-regulated learning, teachers play key roles in the learning processes as to develop students' self-regulated learning by emphasizing goal-oriented learning processes, monitor progress, and modulate the speed of learning for all students. Teachers also function as tutors or coaches who provide information or materials to students, aand give feedback.

Important components of self-regulated learning contribute to academic procrastination through the motivation and self-efficacy. As Slavin [27] puts meticulously, motivation is a desire to achieve success and participate in activities that influence the results obtained from a person's success depending on the efforts and abilities. This research's results show that students who have motivation can measure the goals and values of confidence in a successful learning domain. Students are motivated to directly involve in doing tasks because they feel challenged, and are curious about mastering academic tasks. In addition, students having motivation will be evaluated to know how far the student considers the importance of academic tasks affecting the academic procrastination.

Regardless of the motivation, the main determining factor in developing self-regulated learning is self-efficacy. Confidence in the ability of self-regulation refers to the students' beliefs that they can develop behaviors needed to organize themselves in the learning processes. Zimmerman, Bandura \& Martinez-Pons (in [11]) outline that self-efficacy includes self-belief in the ability to be successful in academic tasks.

While doing mathematics homework or academic assignments, students who have high self-regulated learning use effective learning strategies attracted to the materials being taught, well-prepared for the materials learned in the classroom, and participate in advance by asking more questions or expressing ideas during in-class discussions, and clarify the difficulties encountered. In contrast, students having low self regulation often fail to implement effective learning strategies, tend to be passive in the learning processes, the efforts made to understand the concepts of materials are minimal and when faced with difficulties in doing tasks, they tend to shy away resulting in the delay to complete the given assignments.

In terms of the third hypothesis test, there is an interaction effect of project-based learning strategies and self-regulated learning on academic procrastination in learning mathematics for junior high school students. The findings of this research confirm that a significant interaction strategy regarded as a driving force for projectbased learning and self-regulated learning strategies influences academic procrastination in the learning of mathematics for junior high school students. In other words, project-based learning strategies are able to decrease academic procrastination in the learning of mathematics influenced by the levels of students' selfregulated learning.

The influence of interaction strategy in implementing project-based learning and self-regulated learning on the academic procrastination in learning mathematics for junior high school students is supported Soedjadi's opinion (in [26]) concerrning the problems in learning mathematics that can be sourced from the components that make up a learning system including inputs (input/students), instrumental inputs (educators, curricula, teaching materials, infrastructure, methods/models/learning strategies), environment (support/participation of parents/society), and outputs. 
The results of this research show learning strategies that play an important role in carrying out learning processes in the classroom. According Wijarnarko (in [20]), one of the challenges for mathematics teachers is to shift the students' impression towards mathematic as a popular subject that trigger fears. Teachers determine the high and low levels of academic procrastination in mathematics. This requires the teachers' creativity to create a classroom atmosphere and learn to be comfortable and enjoyable, so that they can create more meaningful learning activities.

Students are more active in the learning processes as an integral part of necessary self-regulated learning. The occurrence of procrastination indicates failure in selfregulating learning activities (self-regulated learning). Students having self-regulation in this research are able to set goals, plan, and use effective learning strategies. Nevertheless, students having low self-regulation often fail to implement effective learning strategies. Differences in students' self-regulated learning will result in the use of metacognitive strategies by students who become predictors of academic procrastination. Students who monitor the function of metacognitive skills and control the conditions of learning will rarely put off learning. Students do not control academic procrastination through better learning and metacognitive strategies (self-evaluation, self-control, and self-questioning), while procrastinator rarely uses this strategy.

In the mathematics learning, self-regulated learning is required by students. Bell and Pape [4] examine the role of teachers in helping students develop self-regulated learning ability to grasp basic concepts of mathematics. The results show that as the activity takes place in the classroom, teachers can engage students in the process of self-regulation including forethought, performance control and self-reflection, as well as providing instructional support to a developmentally set behavioral strategy that includes observation, imitation, self-control and selfregulation. Students need guidance to implement this stage in the real context in a way that students should be involved in the process of monitoring and evaluating the learning behavior, so that a student may have a selfregulation in learning.

Zhao and Zheng [35] stated that project-based learning emphasizes the importance of self-regulated learning activities. The results of his research explain further that students having self-regulated learning use a higher level of metacognitive strategies. This research shows an understanding that, although self-regulated learning is generally seen as the ability of the individual, it is able to demonstrate an attitude of cooperation with members of the group in the background (setting) of study. Their ability to cooperate and self-regulate learning has an effect on learning outcomes.

In the project-based learning, an intrinsic motivation is also required that is part of the self-regulated learning. The research of Lam et al. [16] showed that an intrinsic motivation is possessed by influential teachers and students in the processes of project-based learning. Through an intrinsic motivation, a teacher has demonstrated indirectly instructional support in the project-based learning processes that affect students' intrinsic motivation. When a teacher is reported to have a high intrinsic motivation in the project-based learning, students tend to receive great support from teachers and reportedly have a high intrinsic motivation in their learning experience.

The project-based learning strategy is considered appropriate to be applied for the learning of mathematics. Meyer et al. [18] investigated students' motivation and project-based learning strategies in mathematics classes. The research results show that the project applied for the learning of mathematics has an important role in the processes of learning activities, namely (1) students' selfregulated learning to complete tasks essential for the motivation in the classroom, (2) interviews projects to describe how students can deconstruct the most challenging activities, and (3) the cooperation can support students in the testing of their ideas, learn from mistakes, and have resistance during the learning processes. The results also indicate that teachers need to understand how a good teacher encourages students to be more creative during the learning processes. Teachers need to consider how the students use metacognitive strategies, motivation, willingness and affective processes of students in the classroom. It is necessary to support the students' cognitive engagement and persistence when they are faced with difficult academic tasks so that they no longer put off working and completing them.

\section{Conclusion}

There are significant differences in the level of academic procrastination in the learning of mathematics for junior high school students who received project-based learning strategies and junior high school students who received conventional learning strategies. In addition, there are significant differences in the level of academic procrastination in the learning of mathematics for junior high school students who have high self-regulated learning and for junior high school students who have low self-regulated learning. Ultimately, there is an interaction effect of project-based learning strategies and selfregulated learning on the academic procrastination in the learning of mathematics for junior high school students.

\section{Suggestion}

It is necessary to put forward suggestions to lower the level of academic procrastination in the learning of mathematics for junior high school students. To reduce the level of students' academic procrastination in the learning of mathematics, teachers are encouraged to apply a project-based learning strategy, because it has the advantage of lowering the level of students' academic procrastination compared with conventional learning strategies. The tasks in the selected projects must be able to encourage students to conduct in-depth investigation and encourage the responsibility of every student in completing the tasks assigned by the teacher.

Teachers are also encouraged to develop students' selfregulated learning programmatically because the cause of academic procrastination results from a failure of students in self-regulating the learning (the self-regulated learning). The development of students' self-regulated learning is 
believed to increase responsibility for their own learning and can improve academic achievements in schools. The given academic procrastination can come from teachers, so that it is recommended that mathematics teachers are able to give an example of discipline to the students and give good attention to them when doing tasks.

\section{References}

[1] Ardhana, W.K.L. \& Purwanto. 2004. Pembelajaran Inovatif untuk Pemahaman dalam Belajar Matematika dan Sains di SD, SLTP, dan di SMU. Laporan Penelitian Hibah Pasca Angkatan I Tahun II. Tidak diterbitkan. Malang: PPs UM.

[2] Alamaki, A. 1999. Current Trends in Technology Education in Finland. The Journal of Technology Studies. Available on: Digital Library and Archives.

[3] Azwar, S. 2013. Penyusunan Skala Psikologi. Edisi 2. Yogyakarta: Pustaka Pelajar.

[4] Bell, C.V., \& Pape, S.J. 2014. Scaffolding the development of self-regulated learning in mathematics classrooms. Middle School Journal, 45 (4): 23-32.

[5] Blumenfeld, P.C., Soloway, E., Marx, R.W., Krajcik, J.S., \& Palincsar, A. 1991. Motivating Project-Based Learning: Sustaining the Doing, Supporting the Learning. Educational Psychologist, 26 (3 \& 4): 369-398

[6] Borg, W.R., \& Gall, M.D. 2003. Educational Research: An Introduction. New York: Longman.

[7] Budiyono. 2003. Metodologi Penelitian Pendidikan. Surakarta: Sebelas Maret University Press.

[8] Clark, J.L. \& Hill, O.W. 1994. Academic Procrastination among African-American Colleges Student. Psychological Reports, 75: 931-936

[9] Eerde, W.E. 2000. Procrastination: Self-regulation in Initiating Aversive Goals. Applied Psychology: An International Review, 49 (3): 372-389

[10] Ferrari, J.R., Johnson, J.L., \& McCown, W.G. 1995. Procrastination and Task Avoidance. Theory, Research, and Treatment. (Snyder, C.R., Ed). New York: Plenum Press.

[11] Fetsco, T., \& McClure, J. 2005. Educational Psychology: an integrated approach to classroom decisions. Boston: Pearson Education, Inc.

[12] Fitzmaurice, M., \& Donnely, R. 2005. Collaborative ProjectBased Learning and Problem Based Learning in Higher Education: A Consideration of Tutor and Student Roles in Learner-focused Strategies. Dublin: Learning and Teaching Centre Dublin Institute of Technology.

[13] Gravemeijer, K. 1994. Developing Realistic Mathematics Education. Utrecht: Freudental Institute.

[14] Kementerian Pendidikan dan Kebudayaan. 2013. Materi Pelatihan Implementasi Kurikulum 2013. Jakarta: Badan Pengembangan SDM Pendidikan dan Kebudayaan dan Penjaminan Mutu Pendidikan Kemendikbud.

[15] Kerlin, B.A. 2000. Engangement Style, Self-Regulated Learning and Cooperative Learning. http://www.lrn.pdx.edu/kerlin $\mathrm{b} / \mathrm{myresearch} / \mathrm{srl}$.

[16] Lam, S., Cheng, R.W., \& Ma, W.Y.K. 2009. Teacher and student intrinsic motivation in project-based learning. Instructional Science, 37: 565-578.

[17] Lorsbach, A., \& Tobin, K. 1992. Constructivism as a referent for Scince Teaching. NARST Research Matters-to the Science Teacher, 30 .
[18] Meyer, D.K., Turner, J.C., \& Spencer, C.A. 1997. Challenge in a mathematics classroom: Students' motivation and strategies in project based learning. The Elementary School Journal, 97 (5): 501-521.

[19] Nasir, M. 1998. Metode Penelitian. Jakarta: Ghalia.

[20] Pais. 2009. Meningkatkan Pemahaman Konsep Bangun Ruang dengan Metode Penemuan di MTsN Kepanjen. Tesis tidak diterbitkan. Malang: Program Pascasarjana Universitas Negeri Malang.

[21] Pintrich, P.R., Smith, D.A.F., Garcia, T., \& McKeachie, W.J. 1991 A Manual for the Use of the Motivated Strategies for Learning Questionnaire (MSLQ). Michigan: The University of Michigan.

[22] Purworini, S.E. 2006. Pembelajaran Berbasis Proyek Sebagai Upaya Mengembangkan Habit of Mind. Studi Kasus di SMP Nasional KPS Balikpapan. Jurnal Pendidikan Inovatif, 1 (2).

[23] Richmond, G., \& Striley, J. 1996. Making Meaning in Classrooms: Social Processes in Small-Group Discourse and Scientific Knowledge Building. Journal of Research in Science Teaching, 33 (8): 839-858.

[24] Schraw, G. Wadkins, T., \& Olafson, L. 2007. Doing the things we do: A grounded theory of academic procrastination. Journal of Educational Psychology, 99 (1): 12-25.

[25] Schunk, D.H. 2012. Learning Theories. An Educational Perspective. Terjemahan Hamdiah, E. \& Fajar, E. 2012. Yogyakarta: Pustaka Pelajar.

[26] Siswono, T.Y.E. 2014. Permasalahan Pembelajaran Matematika dan Upaya Mengatasinya. Makalah disajikan pada Diskusi Panel dan Workshop Program Studi S2 Pendidikan Matematika. Pascasarjana Universitas Mahasaraswati Denpasar, 18 Januari 2014.

[27] Slavin, R. 2006. Educational Psychology: Theory and Practice. Boston: Allyn and Bacon.

[28] Smith, P.A. 2001. Understanding Self-Regulated Learning and Its Implications for Accounting Educator and Research. Issues in Accounting Educationm 16 (40): 663-667.

[29] Steel, P. 2007. The nature of procrastination: A meta-analytic and theoretical review of quintessential self-regulatory failure. Psychological Bulletin, 133 (1): 65-94.

[30] Tice, D.M. \& Baumeister, R.F. 1997. Longitudinal study of procrastination, performance, stress, and health: The Cost and benefits of Dawdling. Psychological Science, 8 (6): 454-458.

[31] Thomas, J.W. 2000. A Review of Project Based Learning. A Report prepared for The Autodesk Foundation. San Rafael, CA. (online). (http://www.bie.org/files/researchreviewPBL_1.pdf), diakses 13 Maret 2015.

[32] Tuckman, B.W. 1991. The Development and Concurrent Validity of The Procrastination Scale. Educational and Psychological Measurement, 5: 473-480.

[33] Wolters, C. A. 2003. Understanding procrastination from a selfregulated learning perspective. Journal of Educational Psychological, 95 (1): 179-187.

[34] Zeenath, S., \& Orcullo, D.J.C. 2012. Exploring Academic Procrastination among Undergraduates. DOI: 10.7763/IPEDR. V47.9.

[35] Zhao, K. \& Zheng, Y. 2014. Chinese Business English Students' Epistemological Beliefs, Self-Regulated Strategies, and Collaboration in Project-Based Learning. Asia-Pacific Education Research, 23 (2): 273-286.

[36] Zimmerman, B.J. 2000. Attaining Self-Regulation. In M. Boekaerts, P. R. Pintrich \& M. Zeidner (Eds.). Handbook of SelfRegulation. San Diego, C.A: Academic Press.

[37] Zimmerman, B.J., \& Moylan, A.R. 2009. Self-Regulation: Where Metacognition and Motivation Intersect. Dalam Hacker, D.J. (Eds.), Handbook of Metacognition in Education (hlm. 299-316). New York: Routledge. 